\title{
Calculated variations of annual ice ablation at the margin of the Greenland ice sheet, West Greenland, 1961-90
}

\author{
Roger J. Braithwaite, Ole B. Olesen and Henrik Højmark Thomsen \\ Gronlands Geologiske Undersegelse, DK-1350 Kobenhavn K, Denmark
}

\begin{abstract}
Annual ice ablation has been measured at three locations at the margin of the Greenland ice sheet: Nordbogletscher (for 6 years: 1977-78 to 198283), Qamanârssûp sermia (8 years: $1979-80$ to 1986-87) and at Paakitsup Akuliarusersua ( 7 years: $1982-83$ to the present). As the data sets cover different periods, it is difficult to compare ablation directly between the three sites. However, measured series at each site can be extended over the last 30 years (1961-90) by simulations using climatic data, and the extended data series can be compared. The pattern of calculated ablation variations at the three locations is remarkably similar with no sign of any trend towards increased ablation in recent years. There was generally low ablation from the mid-1970s to the mid-1980s that may explain the recent thickening of the ablation area which has been detected by satellite radar altimetry. Ablation varies substantially from year to year, e.g. with a standard deviation of the order of $\pm 0.5 \mathrm{~m}_{\text {water }}{ }^{-1}$, and any future monitoring programme must detect trends of increasing ablation against this background of natural variations.
\end{abstract}

\section{INTRODUGTION}

There is public concern that higher temperatures due to the greenhouse effect will cause increased melting of the Greenland ice sheet and will contribute to a rise in world sea level. For example, melting at the margin of the ice

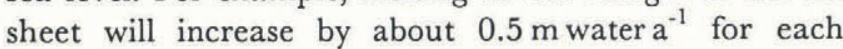
degree increase in summer temperature, giving a sea-level rise of about $0.2-0.4 \mathrm{~mm} \mathrm{a}^{-1} \mathrm{deg}^{-1}$ (Braithwaite and Olesen, 1990b; Huybrechts and others, 1991).

There is a popular perception that climatic warming has already started. It is therefore interesting that recent measurements by satellite altimetry (Zwally and others, 1989) show that the southern part of the Greenland ice sheet thickened since the mid-1970s (Table 1). This finding has been questioned on technical grounds, e.g. see

Table 1. Average thickening rate for the southern part of the Greenland ice sheet (Zwally and others, 1989)

$\begin{array}{cc}\text { Satellite } & \text { Thickening } \\ \mathrm{m} \mathrm{a}^{-1} & \text { Period }\end{array}$

$\begin{array}{lll}\text { GEOS-3-Seasat } & 0.11 \pm 0.14 & \text { April 1975-June 1978 } \\ \text { Geosat-Seasat } & 0.20 \pm 0.06 & \text { July 1978-October 1985 } \\ \text { Geosat-Geosat } & 0.28 \pm 0.02 & \text { April 1985-September } \\ & & \end{array}$

comments by Douglas and others (1990) and the response by Zwally and others (1990), but Zwally (1989) suggested the thickening is caused by increased precipitation in connection with a warmer climate.

The study by Zwally and others (1989) refers to thickness changes averaged over both the accumulation and ablation areas. A smaller thickening of the accumulation area has already been detected by other workers, e.g. $0.03-0.06 \mathrm{~m} \mathrm{a}^{-1}$ (Reeh and Gunderstrup, 1985; Kostecka and Whillans, 1988), and we do not discuss here elevation changes in the accumulation area. However, the satellite measurements also show that the ablation area thickened (Zwally, 1989, fig. 3) in strong contrast to the general retreat of the ice margin since the last century (Weidick, 1959), although there are now signs of a re-advance at many places (Weidick, 1991). The rate of thickening averaged over the ablation area (700-1200 $\mathrm{m}$ a.s.l.) of the southern part of the Greenland ice sheet $\left(60-72^{\circ} \mathrm{N}\right)$ was $0.19 \pm 0.15 \mathrm{~m} \mathrm{a}^{-1}$ for $1978-85$ (personal communication from H.J. Zwally) which is almost identical with the thickening averaged over both the ablation and accumulation areas together.

Ablation is a key process for understanding the surface changes in the marginal zone of the Greenland ice sheet. We therefore analyse recent ablation variations in an attempt to explain the thickening of the ablation area found by satellite radar altimetry.

\section{ABLATION DATA}

Ablation has been measured at three sites (Fig. 1) in the margin zone of the Greenland ice sheet, West Greenland, 


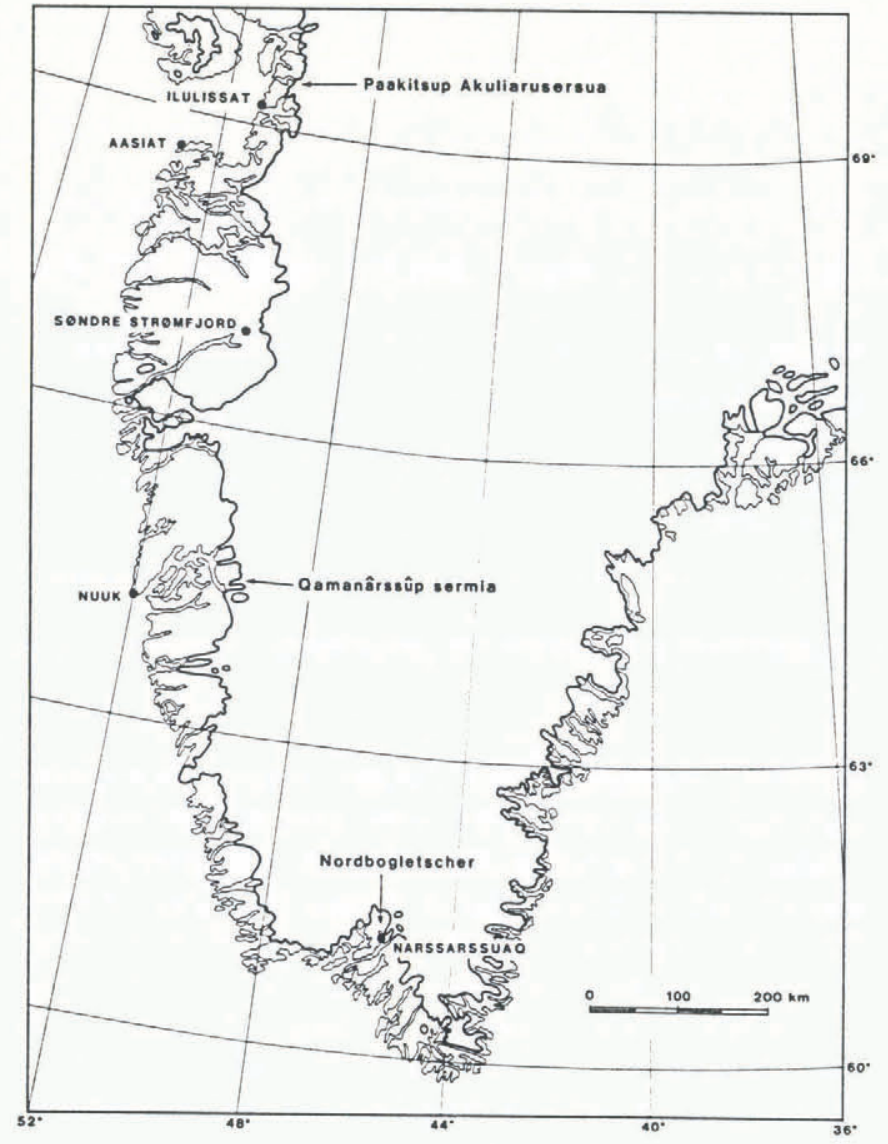

Fig. 1. Glacier-climate stations at the margin of the Greenland ice sheet with long-term climate stations at the coast, West Greenland.

since the late 1970 s to plan hydro-electric power stations (Olesen and Braithwaite, 1989). The data refer to annual ice ablation or net ablation, i.e. "Eis-Nettoablation" (Ambach, 1972), averaged over a number of stakes drilled into the ice in the ablation area. The measurement year is from September to August at Nordbogletscher and Qamanâr'ssûp sermia, and for mid-May to mid-May at Paakitsup Akuliarusersua which essentially includes the ablation season from late May to late August (the last stake readings of each year are made in mid-August). The data are analysed using the simple linear model of Lliboutry (1974) to calculate the net ablation deviation $\beta_{t}$ :

$$
y_{i t}=\alpha_{i}+\beta_{t}+\epsilon_{i t}
$$

where $y_{i t}$ is the net ablation at stake $i$ in the year $t, \alpha_{i}$ varies with stake, $\beta_{t}$ varies with year and $\epsilon_{i t}$ varies with both year and stake. The variable $\beta_{t}$ is the climate signal (Braithwaite and Olesen, 1989a) and $\epsilon_{i t}$ is the random noise caused by measurement errors, variations in local topography, etc. By assumption, both climate signal $\beta$ and noise $\epsilon$ are stationary random processes, and noise at any particular stake is assumed to be uncorrelated with climate signal as well as being uncorrelated with noise at other stakes, although systematic measurement errors at many stakes will affect $\beta_{t}$. The model is useful if the noise is relatively small compared with the signal. For example, at Qamanârssûp sermia, the standard deviations of $\beta_{t}$ and $\epsilon_{i t}$ are \pm 0.55 and $\pm 0.28 \mathrm{~m}$ water $\mathrm{a}^{-1}$, respectively (Braithwaite and Olesen, 1989b). This gives a signalnoise variance ratio $(\beta / \epsilon)^{2}$ of about 3.9.
The model in Equation (1) cannot only be used to analyse net ablation variations in complete data sets but can also be used for estimating missing data. For example, a missing value at a certain stake for a particular year can be estimated by assuming that it would have the same deviation from the long-term mean for that stake as other stakes have from their long-term means, i.e. similar to the "method of differences" used in climatology (Conrad, 1944, p. 148).

The data from Nordbogletscher comprise a complete data set with 14 stakes for 6 years (1977-78 to 1982-83) as used by Braithwaite and Olesen (1988a, b). The stakes are clustered in a relatively narrow altitude band from 860 to $910 \mathrm{~m}$ a.s.l. (far below the equilibrium line at about $1500 \mathrm{~m}$ a.s.l.), so that ablation differences between stakes are fairly small.

The Qamanârssûp sermia data set comprises incomplete data on 14 stakes for 8 years (1979-80 to 1986-87). The stakes extend from near sea level to close to the equilibrium line, i.e. from 110 to $1410 \mathrm{~m}$ a.s.l. There are therefore large differences in ablation between high and low stakes as well as variations between years. The data are based on the complete data set for eight stakes in 6 years (1980-81 to 1985-86) discussed by Braithwaite and Olesen (1989b) but is extended to two further years, i.e. 1979-80 and 1986-87, and six further stakes by estimation of missing data using Equation (1).

The Paakitsup Akuliarusersua data set comprises incomplete data on ten stakes for 7 years (1982-83 to 1988-89)(Thomsen, 1984; Thomsen and Olesen, 1990). The stake elevations are from 240 to $1070 \mathrm{~m}$ a.s.l. There are again large differences between stakes as well as between years. Missing data are estimated using Equation (1).

The three ablation series, whose deviations are shown in Table 2, are short, do not cover exactly the same

Table 2. Net ablation deviations in West Greenland. Units are $m$ water $a^{-1}$

\begin{tabular}{lrrr}
\hline \multicolumn{1}{c}{ Year } & $\begin{array}{c}\text { Nordbo- } \\
\text { gletscher }\end{array}$ & $\begin{array}{c}\text { Qamanârssûp } \\
\text { sermia }\end{array}$ & $\begin{array}{c}\text { Paakitsup } \\
\text { Akuliarusersua }\end{array}$ \\
\hline 1977-78 & 0.28 & & \\
$1978-79$ & -0.33 & & \\
$1979-80$ & 0.62 & -0.14 & \\
$1980-81$ & 0.30 & 0.10 & \\
$1981-82$ & 0.03 & 0.02 & -0.83 \\
$1982-83$ & -0.89 & -0.83 & -0.01 \\
$1983-84$ & & -0.70 & 0.56 \\
$1984-85$ & & 0.68 & -0.45 \\
$1985-86$ & & 0.27 & 0.48 \\
$1986-87$ & & 0.61 & 0.35 \\
$1987-88$ & & & -0.13 \\
$1988-89$ & & & 0.00 \\
\hline Mean & 0.00 & 0.00 & \pm 0.51 \\
s.d. & \pm 0.54 & \pm 0.55 & \\
\hline
\end{tabular}


periods and do not fully cover the periods with satellitealtimetry data shown in Table 1 . It is therefore difficult to compare ablation deviations directly beyond noting that they all agree in showing very low ablation for 1982-83 (the only year common to all three series), while the Qamanârssûp sermia and Paakitsup Akuliarusersua series also agree in showing high ablation for both 1984-85 and 1986-87.

To overcome the above shortcomings in the data, the approach of the present paper is (1) to relate ablation deviations at each site to suitable climate data at nearby weather stations, (2) to use the climate data to simulate net ablation deviations over the 30 years, 1961-90, and (3) to compare the simulated net ablation series with each other, and with the satellite-altimetry data.

\section{GLIMATE DATA}

Some long-term weather stations are operated on the coast of Greenland by the Danish Meteorological Institute, Copenhagen. The stations used for the present study are Narssarssuaq for correlation with Nordbogletscher, Nuuk (formerly called Godthåb) for Qamanârssûp sermia and Ilulissat (formerly Jakobshavn) for Paakitsup Akuliarusersua (Fig. 1).

Data for monthly mean temperatures and monthly precipitation totals are published in annual summaries for 1961 to 1981 , while unpublished data for 1982-90 were kindly provided by P. Frich, Database Section, Danish Meteorological Institute.

The climate data for Narssarssuaq can be used without problems, whereas the data from Nuuk and Ilulissat require some manipulation. In the case of Nuuk, the weather station was relocated at the end of 1981 and all precipitation totals before that date are corrected with a factor of 0.9 (Førland and Nordli, 1990). Temperature observations were not made at all synoptic hours at Ilulissat, so the monthly mean temperature is calculated as the monthly mean of daily maximum and minimum temperatures, i.e. as in Canada, rather than the monthly mean of $3 \mathrm{~h}$ temperatures as at Narssarssuaq and Nuuk. More seriously, observations were stopped at Ilulissat in 1985 (after more than a century of observations!) so that data after 1985 are extrapolated from the nearby station at Aasiat (formerly Egedesminde) using correlations between the two stations for 1961-85 data.

\section{SIMULATION OF ABLATION}

In principle, net ablation deviations in Greenland can be simulated with a simple degree-day model (Braithwaite and Olesen, 1989a), a precipitation-corrected degree-day model (Braithwaite and Olesen, 1988b), or with a full energy-balance model (Braithwaite and Olesen, 1990a). However, for the present study it is better to use simple data over a long period, i.e. from weather stations on the coast. It was therefore decided to correlate ablation with summer temperature and annual precipitation following Martin (1974). The summer mean here refers to JuneAugust while the precipitation year is September-August.

At all three sites, the net ablation deviation is
Table 3. Correlation coefficients between net ablation deviation $\beta$, summer mean temperature $T$ and annual precipitation $P$

\begin{tabular}{|c|c|c|c|c|}
\hline Site & Years & $R(\beta, T)$ & $R(\beta, P)$ & $R(T, P)$ \\
\hline Nordbogletscher & 6 & $0.77^{*}$ & -0.72 & -0.44 \\
\hline $\begin{array}{l}\text { Qamanârssûp } \\
\text { sermia }\end{array}$ & 8 & $0.83^{*}$ & $-0.79^{*}$ & -0.55 \\
\hline $\begin{array}{l}\text { Paakitsup Akul- } \\
\text { iarusersua }\end{array}$ & 7 & $0.77^{*}$ & $-0.74^{*}$ & -0.68 \\
\hline
\end{tabular}

${ }^{*}$ Significant at less than $5 \%$ probability.

positively correlated with summer mean temperature and negatively correlated with annual precipitation (Table 3). The increase of ice ablation with temperature mainly reflects the increase in energy from sensible-heat flux and longwave radiation, while the decrease with precipitation partly reflects the effect of increased snow accumulation which delays the onset of ice ablation (Braithwaite and Olesen, 1990c). There is also a moderate negative correlation between summer temperature and annual precipitation.

Net ablation deviations at Nordbogletscher are given by the multiple regression equation:

$$
\beta_{t}=-3.17+0.44 T_{t}-1.24 P_{t} \quad R^{2}=0.77
$$

where $T_{t}$ is summer mean temperature (June-August) and $P_{t}$ is annual precipitation (September-August) at Narssarssuaq. Both $\beta_{t}$ and $P_{t}$ are in m water $\mathrm{a}^{-1}, T_{t}$ is in ${ }^{\circ} \mathrm{C}$, and $R$ is the multiple-regression coefficient. The regression equation for Qamanârssûp sermia is:

$$
\beta_{t}=-1.26+0.37 T_{t}-1.14 P_{t} \quad R^{2}=0.85
$$

where $T_{t}$ and $P_{t}$ are here from Nuuk. The corresponding equation for Paakitsup Akuliarusersua is:

$$
\beta_{t}=-1.08+0.32 T_{t}-3.39 P_{t} \quad R^{2}=0.68
$$

where $T_{t}$ and $P_{t}$ are here from Ilulissat, supplemented with data from Aasiat (see above).

The sample sizes are small so the equations are influenced by sampling errors. Instead of calculating confidence intervals, it is more useful in the present case to use the criterion of Fiering (1963), the minimum value of the multiple-correlation coefficient $R_{\mathrm{c}}$ which is "useful":

$$
R_{\mathrm{c}}{ }^{2}=2 /(N-2)
$$

where $N$ is the sample size. For Nordbogletscher, $N=6$ and $R_{c}{ }^{2}=0.50$, for Qamanârssûp sermia, $N=8$ and $R_{\mathrm{c}}{ }^{2}=0.33$, and for Paakitsup Akuliarusersua, $N=7$ and $R_{c}{ }^{2}=0.40$. According to this criterion, all three regression equations give useful information.

The intercepts in the equations are arbitrary and comparisons are meaningless. However, there is a broad similarity in the respective temperature coefficients, i.e. $0.32-0.44 \mathrm{~m}$ water $\mathrm{a}^{-1} \mathrm{deg}^{-1}$, and little agreement between the precipitation coefficients beyond the negative sign, i.e. 
-1.14 to -3.39 . One can speculate that lower temperature coefficients at Qamanârssûp sermia and Paakitsup Akuliarusersua, compared with Nordbogletscher, may reflect the higher elevations, and consequent lower average temperatures, of the measuring stakes at the former sites. For present purposes, the equations are simply tools to estimate ablation and are not further discussed here.

\section{ABLATION VARIATIONS}

Net ablation deviations are calculated for the 30 years 1961-90 using Equations (2)-(4) and climate data for Narssarssuaq, Nuuk and Ilulissat, respectively. For convenience in comparing the simulated series, they are re-sampled so that their mean values for 1961-90 are zero. The shorter observed series are similarly shifted for plotting in Figures 2-4.

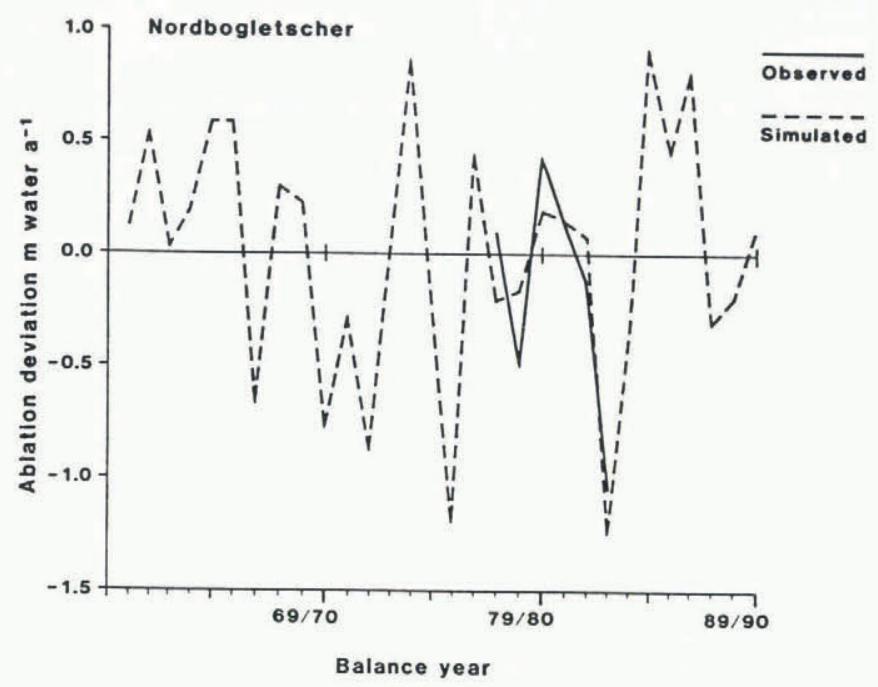

Fig. 2. Net ablation deviations at Nordbogletscher. The solid line is measured data, and the dotted line is calculated from summer temperature and annual precipitation at Narssarssuaq.

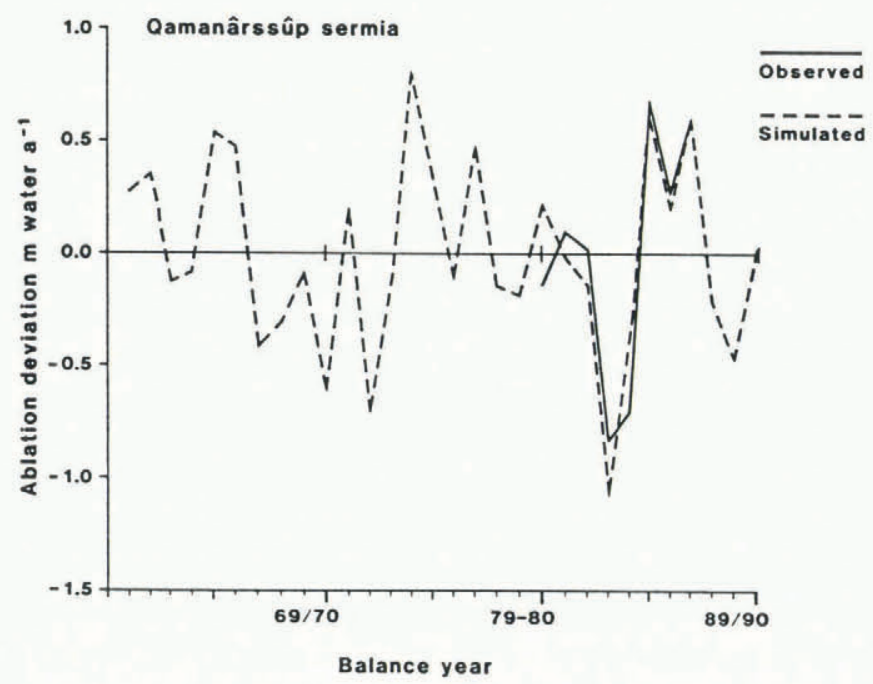

Fig. 3. Net ablation deviations at Qamanârssûp sermia. The solid line is measured data, and the dotted line is calculated from summer temperature and annual precipitation at Nuuk.

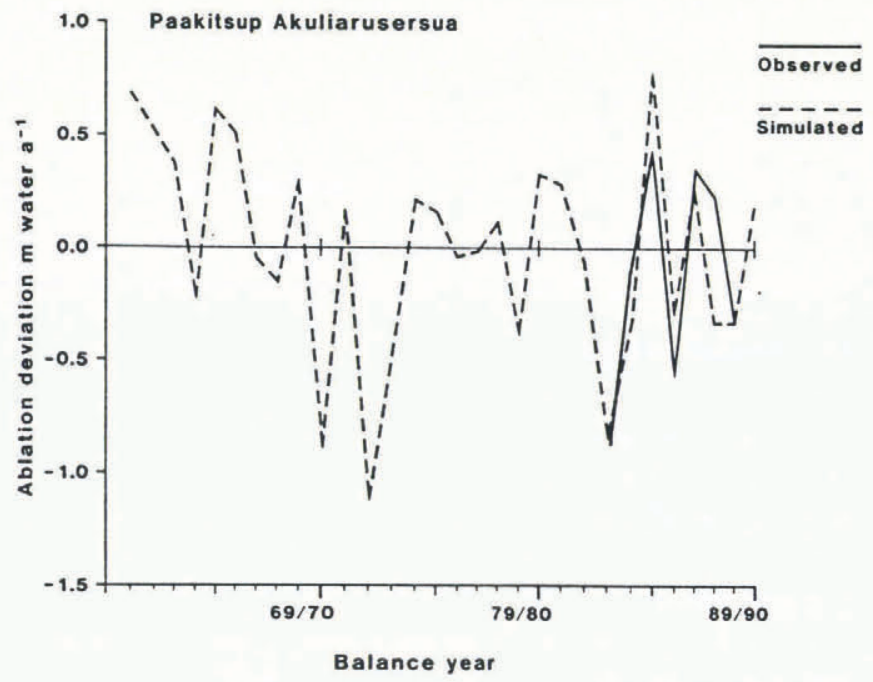

Fig. 4. Net ablation deviations at Paakitsup Akuliarusersua. The solid line is measured data, and the dotted line is calculated from summer temperature and annual precipitation at Ilulissat.

The observed and simulated series show good agreement where they overlap as already shown by the high multiple-correlation coefficients. Although the sites are separated by hundreds of kilometres, the simulated net ablation series show a similar pattern of variations over the 30 years. For example, there are reasonably high correlations between neighbouring series, i.e. between Nordbogletscher and Qamanârssûp sermia, and between Qamanârssûp sermia and Paakitsup Akuliarusersua (Table 4). In particular, all three series have high net ablation in 1973-74, 1984-85 and 1986-87, and low net ablation in 1982-83. On the other hand, low net ablation in 1975-76 at Nordbogletscher was not replicated at the other sites because the very high precipitation in that year in south Greenland (as noted by data at several other stations near to Narssarssuaq) did not penetrate to the more northerly locations. Ablation variations are therefore similar over large areas, but not identical. For convenience, a fourth series is calculated as the average of the three series discussed above.

There are substantial variations in net ablation from year to year which appear to be random with a standard deviation of the order of $\pm 0.5 \mathrm{~m}$ water $\mathrm{a}^{-1}$. This means

Table 4. Correlation coefficients between simulated net ablation deviations. Sample size is 30 years

$\begin{array}{lcc}\text { Nordbo- } & \text { Qamanârssûp } & \text { Paakitsup } \\ \text { gletscher } & \text { sermia } & \text { Akuliarusersua }\end{array}$

$\begin{array}{llll}\text { Nordbogletscher } & 1.00 & 0.82 & 0.68 \\ \text { Qamanârssûp } & & 1.00 & 0.79 \\ \quad \text { sermia } & & & \\ \begin{array}{l}\text { Paakitsup Akul- } \\ \quad \text { iarusersua }\end{array} & & & 1.00 \\ \end{array}$


Table 5. Means of simulated net ablation deviations for different periods. Units are mwater $a^{-1}$

\begin{tabular}{ccc}
\hline Period & Nordbogletscher & Qamanârssûp \\
& sermia & Paakitsup \\
Akuliarusersua
\end{tabular}

\section{Measurement periods}

$1977-78$ to $82-83$

$1979-80$ to $86-87$

0.00

$-0.17$

$1982-83$ to $88-89$

Standard periods

$1960-61$ to $64-65$

$1965-66$ to $69-70$

$1970-71$ to $74-75$

$1975-76$ to $79-80$

$1908-81$ to $84-85$

$1985-86$ to $89-90$

$\begin{array}{rr}0.30 & 0.20 \\ -0.06 & -0.18 \\ -0.12 & 0.09 \\ -0.19 & 0.06 \\ -0.10 & -0.20 \\ 0.17 & 0.02\end{array}$

$$
\begin{array}{r}
0.40 \\
-0.06 \\
-0.20 \\
0.00 \\
-0.04 \\
-0.10
\end{array}
$$

\begin{tabular}{|c|c|c|c|c|}
\hline $\begin{array}{l}\text { Mean } \\
\text { s.d. }\end{array}$ & $\begin{array}{r}0.00 \\
\pm 0.56\end{array}$ & $\begin{array}{r}0.00 \\
\pm 0.45\end{array}$ & $\begin{array}{r}0.00 \\
\pm 0.47\end{array}$ & $\begin{array}{r}0.00 \\
\pm 0.45\end{array}$ \\
\hline
\end{tabular}

that a period of a few years can have much greater or less ablation than the long-term average simply due to statistical effects (Table 5). Net ablation for the 6 years of measurement at Nordbogletscher was relatively low on average compared with the base period 1961-90, i.e. the measurements were made in a relatively cool period. Net ablation at Qamanârssûp sermia for the 8 years of measurement was close to average for the last 30 years, and measurements at Paakitsup Akuliarusersua were again made in a relatively cool period.

There are no signs of any simple trend towards higher ablation in recent years. If anything, average net ablation in the early 1960s was relatively high, followed by low net ablation from the late 1960s until the mid 1980s. Similar indications against increased glacier melting in recent years have been reported from other high-latitude areas, e.g. Svalbard (Hagen and Liestøl, 1990) and Alaska (Mayo and March, 1990).

\section{ABLATION VARIATIONS AND THIGKNESS CHANGES}

It is difficult to compare the ablation variations directly with thickness changes from satellite altimetry because of differences of coverage in space and time. For example, the ablation data only come from three sites on the ice margin while the satellite data refer to averages over the whole southern part of the ice sheet. On the other hand, the satellite data may be influenced by seasonal variations in accumulation and ablation on account of their irregular sampling periods, e.g. see figure 3 in Lingle and others (1990).

The annual thickness change of the ice surface at a site $\mathrm{j}$ in the ablation zone is given by the difference between the emergence velocity of ice flow $v_{j t}$ and the local ablation rate $y_{j t}$ :

$$
\Delta h_{j t}=v_{j t}-y_{j t} / \rho
$$

where $\rho$ is the density of ice. Emergence velocity is probably rather constant with time over periods of a few years, i.e. $v_{j t}=\gamma_{j}$ the long-term mean velocity at site $\mathrm{j}$. Ablation varies between years according to Equation (1) so that:

$$
\Delta h_{j t}=\gamma_{j}-\alpha_{j} / \rho-\beta_{t} / \rho
$$

where $\alpha_{j}$ is here the 30 year mean ablation at site $\mathrm{j}$, and $\beta_{t}$ is the net ablation deviation. According to Equation (6), thickness changes should have a steady trend given by the difference between mean emergence velocity and mean ablation, and a year-to-year fluctuation given by the ablation deviation. The magnitude of the trend $\left(\gamma_{j}-\alpha_{j} / \rho\right)$ is not generally known and, although it may be small as a regional average, it need not be zero, i.e. the long-term mean of emergence velocity is not generally in equilibrium with the 30 year mean ablation.

Average net ablation deviations for periods with satellite altimetry are shown in Table 6. The GEOS-3Seasat comparisons (1975-78) were made in a period of low net ablation at Nordbogletscher, and higher net ablation at Qamanârssûp sermia and Paakitsup Akuliarusersua, i.e. -0.31 to $+0.14 \mathrm{~m}$ water $\mathrm{a}^{-1}$. This is consistent with the thickening of $+0.11 \pm 0.14 \mathrm{~m} \mathrm{a}^{-1}$ detected by satellite altimetry for the same period (Table 1). The Geosat-Seasat comparisons (1978-85) were also made in a period of relatively low ablation at all three sites, i.e. -0.14 to $-0.02 \mathrm{~m}$ water $\mathrm{a}^{-1}$, which is again consistent with the thickening of $+0.20 \pm 0.06 \mathrm{~m} \mathrm{a}^{-1}$. The average of net 
Table 6. Means of simulated net ablation deviations for periods covered by satellite altimetry. Units are $m$ water $a^{-1}$

Period

Nordbogletscher
Qamanârssûp
sermia
Paakitsup

Akuliarusersua
Average

$\begin{array}{rrr}0.14 & 0.06 & -0.04 \\ -0.14 & -0.02 & -0.08 \\ 0.41 & 0.24 & 0.44\end{array}$

08
$1974-75$ to $77-78$

$1977-78$ to $84-85$

$1984-85$ to $85-86$

$\begin{array}{rr}-0.31 & 0.14 \\ -0.09 & -0.14 \\ 0.69 & 0.41\end{array}$

0.24 ablation deviations for $1977-78$ to $1984-85$ (Table 6) is nearly twice the average for $1974-75$ to $1977-78$, i.e. -0.08 to -0.04 , and the corresponding thickness changes in Table 1 are in almost the same ratio, i.e. $0.20-0.11$. One should not overstress this agreement for only two periods, but it illustrates the potential value of comparing satellite- altimetry data for different periods, e.g. on an annual basis if such data are available.

The period 1984-85 to $1985-86$ had relatively high net ablation while the Geosat-Geosat comparison shows a thickening of $0.28 \pm 0.02 \mathrm{~m} \mathrm{a}^{-1}$ for combined accumulation and ablation areas for the 18 months, April 1985 to September 1986 (Zwally and others, 1989). There was also a relative thickening of the ablation area on its own between summer 1985 and summer 1986 of $0.5 \mathrm{~m}$ ice (Lingle and others, 1990). This is consistent with high net ablation for 1984-85 (September 1984-August 1985) and lower ablation for $1985-86$, i.e. +0.77 and $+0.12 \mathrm{~m}$ water $\mathrm{a}^{-1}$, respectively, whereby the relative thickening for 1985-86 represents the partial recovery from the large thinning caused by high ablation in 1984-85.

If the negative ablation deviations in Table $6 \mathrm{did}$ indeed cause the observed thickening of $0.11-0.20 \mathrm{~m} \mathrm{a}^{-1}$ for 1975-78 and 1978-85, respectively, the mean ablation

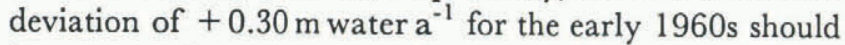
have caused a thinning. By the same token, slightly above-average ablation in the late 1980s should have reversed the thinning trend detected by satellite altimetry.

\section{CONCLUSION}

Ice ablation at the margin of the Greenland ice sheet varies substantially from year to year. The pattern of ablation variations at the three locations is remarkably similar with no sign of any trend towards increased ablation in recent years.

The thickening of the ablation area detected by satellite altimetry from the mid-1970s to the mid-1980s could be due to the generally low ablation in the same period. If this is correct, the thickening was preceded by high ablation in the early 1960s and was reversed by high ablation in the late 1980s. In other words, the observed thickening was probably a transient phenomenon without any long-term effect on the volume of the Greenland ice sheet or world sea level. This can be tested by continued satellite altimetry.

A future monitoring programme for the Greenland ice sheet needs to detect long-term changes against a background of natural variations.

\section{RECOMMENDATIONS}

Satellite altimetry is an attractive tool for monitoring changes of the Greenland ice sheet in the long term, and at large scale, but close co-ordination is needed between satellite measurements and data collection in the field to improve interpretation. The presentation of satellitealtimetry data should also be refined if possible: (1) elevation changes should be determined separately for ablation and accumulation areas because different glacier-climate processes are involved and because measurements involve different errors in the two areas, (2) altimetry results should be referred to a "natural" glaciological year as thickness changes contain strong seasonal components, and (3) elevation changes for different parts of the ice sheet (in metres) should be expressed as water equivalents using the appropriate snow/ice density from ground surveys.

\section{ACKNOWLEDGEMENTS}

This paper is published by permission of The Geological Survey of Greenland (GGU). The three GGU field stations were partly funded by the Regional Development Programme of the European Community (EC) and partly by the Danish Energy Ministry. Data for 1980 83 at Nordbogletscher were collected by P. Clement. Error-checked climate data from Greenland weather stations for 1982-90 were provided by P. Frich, Danish Meteorological Institute, Copenhagen, Denmark. Valuable comments on the satellite altimetry were made $\mathrm{H}$.J. Zwally (NASA, Greenbelt, Maryland, U.S.A.) and C.S. Lingle (University of Alaska, Fairbanks, U.S.A.), although we are responsible for any shortcomings in this study.

\section{REFERENCES}

Ambach, W. 1972. Zur Schätzung der Eis-Nettoablation im Randgebiet des grönländischen Inlandeises. Polarforschung, 42(1), 18-23.

Braithwaite, R.J. and O.B. Olesen. 1988a. Effect of glaciers on annual run-off, Johan Dahl Land, south Greenland. F. Glaciol., 117(34), 200-207. 
Braithwaite, R.J. and O.B. Olesen. 1988b. Winter accumulation reduces summer ablation on Nordbogletscher, south Greenland. Z. Gletscherkd. Glazialgeol., 24(1), 21-30.

Braithwaite, R.J. and O. B. Olesen. 1989a. Calculation of glacier ablation from air temperature, West Greenland. In Oerlemans, J., ed. Glacier fluctuations and climatic change. Dordrecht, Kluwer Academic Publishers, 219233.

Braithwaite, R.J. and O.B. Olesen. 1989b. Detection of climate signal by inter-stake correlations of annual ablation data, Qamanârssûp sermia, West Greenland. 7. Glaciol., 120(35), 253-259.

Braithwaite, R.J. and O.B. Olesen. 1990a. A simple energy-balance model to calculate ice ablation at the margin of the Greenland ice sheet. F. Glaciol., 36(123), 222-228.

Braithwaite, R.J. and O.B. Olesen. 1990b. Increased ablation at the margin of the Greenland ice sheet under a greenhouse-effect climate. Ann. Glaciol., 14, 2022.

Braithwaite, R.J. and O.B. Olesen. 1990c. Response of the energy balance on the margin of the Greenland ice sheet to temperature changes. F. Glaciol., 36(123), 217221.

Conrad, V. 1944. Methods in climatology. Cambridge, MA, Harvard University Press.

Douglas, B. C., R. E. Cheney, L. Miller, R. W. Agreen, W. E. Carter and D. S. Robertson. 1990. Greenland ice sheet: is it growing or shrinking? Science, $\mathbf{2 4 8}$ (4953), 288.

Fiering, M. B. 1963. Use of correlation to improve estimates of the mean and variance. U.S. Geol. Surv. Prof. Pap. 434-C.

Førland, E.J. and P. Ø. Nordli. 1990. Homogenisering av nedbørdata fra Godthåb (Nuuk). Det Norske Meteorologiske Institutt. Rapport 01/90.

Hagen, J. O. and O. Liestøl. 1990. Long-term glacier mass-balance investigations in Svalbard, 1950-88. Ann. Glaciol., 14, 102-106.

Huybrechts, P., A. Letréguilly and N. Reeh. 1991. The Greenland ice sheet and greenhouse warming. Palaeogeogr. Palaeoclimatol. Palaeoecol., 89(4), 399-412.

Kostecka, J. M. and I. M. Whillans. 1988. Mass balance along two transects of the west side of the Greenland ice sheet. F. Glaciol., 34(116), 31-39.

Lingle, C.S., A.C. Brenner and H.J. Zwally. 1990. Satellite altimetry, semivariograms, and seasonal elevation changes in the ablation zone of West Greenland. Ann. Glaciol., 14, 158-163.

Lliboutry, L. 1974. Multivariate statistical analysis of glacier annual balances. F. Glaciol., 13(69), 371-392.

Martin, S. 1975. Corrélation bilans de masse annuelsfacteurs météorologiques dans les Grandes Rousses. Z. Gletscherkd. Glazialgeol., 10, 1974, 89-100.

Mayo, L. R. and R. S. March. 1990. Air temperature and precipitation at Wolverine Glacier, Alaska; glacier growth in a warmer, wetter climate. Ann. Glaciol., 14, 191-194.

Olesen, O. B. and R.J. Braithwaite. 1989. Field stations for glacier-climate research, West Greenland. In Oerlemans. J., ed. Glacier fluctuations and climatic change. Dordrecht, Kluwer Academic Publishers, 207-218.

Reeh, N. and N.S. Gundestrup. 1985. Mass balance of the Greenland ice sheet at Dye 3. F. Glaciol., 31(108), 198-200.

Thomsen, H.H. 1984. Mass balance measurements at the margin of the inland ice near Jakobshavn, West Greenland. Polarforschung, 54(1), 37-41.

Thomsen, H.H. and O.B. Olesen. 1990. Continued glaciological investigations with respect to hydropower and ice-climate relationships, at Pâkitsoq, Jakobshavn, West Greenland. Gronl. Geol. Undersogelse. Rapp. 148, 83-86.

Weidick, A. 1959. Glacial variations in West Greenland in historical time. Medd. Gronl., 158(4).

Weidick, A. 1991. Present-day expansion of the southern part of the inland ice. Gron. Geol. Undersogelse. Rapp. 152, 73-79.

Zwally, H.J. 1989. Growth of the Greenland ice sheet: interpretation. Science, 246(4937), 1589-1591.

Zwally, H.J., A. C. Brenner, J.A. Major, R.A. Bindschadler and J. G. Marsh. 1989. Growth of Greenland ice sheet: measurement. Science, 246(4937), 1587-1589.

Zwally, H.J., A. C. Brenner, J.A. Major, R.A. Bindschadler and J. G. Marsh. 1990. Response. Science, 248, 288-289.

The accuracy of references in the text and in this list is the responsibility of the authors, to whom queries should be addressed. 